\title{
Household structure and urban opportunities: Evaluating differences in the accessibility to jobs, education and leisure in São Paulo
}

\author{
Tatiana K. Ferrari
}

Federal University of Minas, Gerais Center for Development and Regional Planning

Flavia da F. Feitosa

Federal University of ABC, Center for Engineering, Modeling and Applied Social Sciences

\section{Diego B. Tomasiello}

University of São Paulo, Polytechnic School, Department of Transportation Engineering

\section{Antônio Miguel V. Monteiro}

\section{National Institute for Space Research, Earth Observation \& Geoinformatics Division}

\begin{abstract}
Household structure has been recognized as an important element of residential location choice. The aim of this work is to understand how the spatial configuration resulting from these location choices could cause differentials in terms of urban life and opportunities. To do so, a weighted gravitational accessibility index is applied to the São Paulo Metropolitan Area to investigate the differences among household structures to distinct types of accessibility (jobs, education and leisure). The results point to a high dis-

parity between accessibility levels, especially in the accessibility to jobs. The household size plays an important role, with lower accessibility levels associated with more members in the household. The study shows that the household composition also has impacts on accessibility and that higher deprivation levels affect single-parent households.
\end{abstract} Article History: Received: July 5, 2020 Revised: May 6, 2021 Accepted: May 16, 2021 Available online: June 30,2021 


\section{Introduction}

Urban accessibility is a fundamental issue to the debate on urban development and the quality of life. In Brazil 84\% of the population lives in urban areas (Brazilian Institute of Geography and Statistics 2010) and is faced with an accelerated and uneven urbanization that has resulted in significant disparities over the urban space, which gives urgency to the accessibility debate. Understanding this issue could help to guide urban planning, inform investments in urban transportation infrastructure and housing policies, and better distribute activities across the territory.

Hansen (1959) introduced the definition of accessibility as the potential of opportunities for interaction. More generally, Couclelis (2000) states: "accessibility is the geographical definition of opportunity." Thus, an important part of the dispute for the intra-urban territory focuses on locations that can offer the best conditions of access to the opportunities available in urban areas.

Accessibility has long been identified as a central issue in the urban theory of residential location. For example, Fujita (1989) asserts that three factors are considered in households' residential location choice: accessibility, space and environmental amenities. Places with good accessibility usually have high prices for space, thus households with many members need to trade space for accessibility. In addition, families with children may consider accessibility to education and leisure as more important than accessibility to work.

These examples illustrate how different household structures are related to different needs, which translate into different displacements, preferences and constraints. The outcome is that we will have a clear differentiation of household structures over the urban space (Beckmann 1973; Ferrari et al. 2019; Jung and Yang 2016).

It is important to highlight that the meaning and implications of household spatial outcome is closely related to the local context. While the literature tends to highlight the trade-off between space and accessibility in the residential location choice, the reality of Latin American countries shows that the majority of families living in peripheral locations, characterized by low levels of accessibility, do not have larger homes. Instead, the location of these families, often in precarious settlements, is associated with an accumulation of disadvantages (Slovic et al. 2019).

A question that we want to explore is how the spatial configuration drawn by different household composition could give rise to differentials in terms of urban life and opportunities, here represented by the accessibility to jobs, education and leisure. Accessibility to mandatory activities (job and education) is important to explore the location of households for most daily activities, but analyze also accessibility to non-mandatory activities (leisure) is key to understanding the potential participation of households in urban social activities that comprises an important part of the urban life(Vecchio et al. 2020).

The characteristics of a household's arrangements and its interaction with the accessibility to different facilities is fundamental in the assessment of the use of urban space. Consequently, the aim of this study is to identify whether there are significant differences in accessibility among different household types, which will provide support for further research on residential location choice.

We applied a gravity-based accessibility measure to a set of facilities (job, education and leisure) for the São Paulo Metropolitan Area (SPMA). Afterwards, we evaluated the disparities among household groups' accessibility to each of these facilities through a relative accessibility index.

The SPMA is the largest urban conglomerate in South America, that has been characterized in general by a center-periphery spatial pattern, with higher status groups located in central and wellequipped areas, while lower status groups live in more distant and poorly-equipped settlements, often in precarious self-constructed dwellings. Over the past few decades, this pattern has become more complex, as some sub-centralities have emerged and the peripheral areas have become more fragmented and heterogeneous (Feitosa et al. 2021; Marques 2016). The observed changes in peripheral areas is understood to be a consequence of the emergence of gated communities for upper classes (Caldeira 
2000) and investments in poor neighborhoods related to the political and economic transformations since Brazil's re-democratization in the 1980s (Arretche 2018; Marques and Bichir 2003).

The remainder of this paper is organized as follows. The next section presents a discussion about accessibility and its relationship with household types. The third section describes the methodology that we have used, including a short description of the study area, a description of the different datasets used, and presents the index used to calculate the accessibility. The fourth section discusses the results of the accessibility index and it will analyze the differences among household types. Our conclusions are presented in section five.

\section{Accessibility and Household Structure}

The spatial configuration of urban spaces are, in general, heterogeneous and organized by agglomerations of similar groups in certain locations. The social differentiation over space has been addressed from many perspectives. From a demographic perspective, household structure has been recognized as an important element of residential location choice. Based on this perspective associated with a more even, equitable and mature urbanization process a large literature is found on understanding the household factors for residential location choice. Although, in cities and regions, like the SPMA, where an uneven, socially unfair, young and accelerated urbanization process takes place a more stratified urban space emerges. It is characterized less by a residential location choice free model and more by an asymmetric struggle for residential locations by social groups to occupy urban locations that favor their accumulation of advantages (Castells 1979; Feitosa et al. 2017). Even though, the residential location choice literature relating household types and their preferences is an important and valuable asset to assess the transport system accessibility in urban spaces with uneven distribution of urban opportunities.

The work of Beckmann (1973) was the first to address the problem of residential location choice considering the perspective of households. Given the number of members per family $(n)$, this model divides them in two groups: $d$, the number of dependent members, and $m$, the number of working members. Following the neoclassical model of von Thunen, the model predict that there are distinct land use zones, one for each household type characterized by $m / n$. The greater the household structure, the greater the consumption of space. In particular, when the number of dependents relative to those who work is greater, the rent that a family can afford to pay for a given space at a certain distance of the city center will be lower.

In addition to size, other characteristics of households are also pointed to influence on residential location choice. According to Kim et al. (2005), residential location choice is a complex function that involves a wide range of attributes of residences and location, where the weight of each of these attributes varies depending on the household. Socioeconomic aspects, such as income and household composition, reflect on different needs and housing consumption behaviors.

Estiri et al. (2015) developed a theoretical model to explain the distribution of households in US metropolitan regions using the lifecycle stages approach. The main argument is that households change their preferences about the neighborhood and housing throughout the stages of the family life cycle, which is divided into three stages based on the age of the household. The results show that younger households are more likely to reside in central city. In the second phase, the households begin to move to suburbs. This movement intensifies in the third phase, where the household seeks more peripheral areas that provide desirable natural amenities.

In this line, Jung and Yang (2016) discuss the suburbanization process in US metropolitan regions and the impact of household structure in this movement. They found that one-person households are more likely to live in central cities than suburbia and that married-couple and extended households are found to be more prevalent in suburbia than central cities. The hypothesis is that one-person households seek the liveliness of the neighborhood in central areas and have temporary housing consumption patterns. In contrast, married-couples with children pursue safety, peaceful and ample spaces on 
the suburbia areas. The same configuration patterns are found by Ferrari et al. (2019) for the case of São Paulo city in Brazil, where one-person households are more likely to live in the central city; married-couple households live in the first ring, surrounding the central city; and the other families are more likely to live in the borders of the city. However, the explanations are quite different. In the case of São Paulo, the authors pointed the household income as the main driver for the location of different families. The hypothesis is that one-person households can afford higher costs of housing in the central region of the municipality because they have no dependents. Meanwhile, the movement of other families to peripheral areas is not followed by an increase in the house spaces.

Unlike the suburbanization process found in Global North countries, Latin America is characterized by a process of peripheralization, where low-income families settle in regions far from the center in large cities. Barros (2012) explored the process of peripheralization of Latin American cities, investigating the residential location process that leads to the segregation of high income groups in the central regions of large urban centers and the peripheralization of lower income groups. In a similar line, Feitosa et al. (2011) explored how public policies could influence urban segregation and, consequently, the location patterns of families with different incomes in a medium-sized Brazilian city.

These location patterns are reflected in the spatial structure of the city. It also has a feedback effect, as the real estate market plays a fundamental role on the segmentation of socio-demographic characteristics over the city. Because the central areas have the highest price of square meter in the city, there is a strong trend towards the intensification of vertical constructions with smaller apartment units. This type of construction may not be seen adequate to larger families. Meanwhile, there is a segmentation in the housing construction in which larger residences, mostly homes with some natural amenities, attract these families to suburbia.

The link between the demographic behaviors and the spatial context is explored by Champion (2001). The discussion of the reshape of urban regions arising from demographic changes was assessed from a theoretical perspective based on the demographic regime in western Europe and many other countries of the developed world. This debate gives rise to several issues that show us the importance of a deeper exploration of these interactions both in terms of the elaboration of public policies as well as in the theoretical debate.

In urban spaces that have undergone a process of an incomplete urbanization (Santos 2013; Santos and Kayser 1971) the models related to residential location choices gain a lot more of complexities. In this study we focus on understand how the spatial configuration already draw by the families living in those households distributed all over the SPMA could give rise to differentials in terms of their urban opportunities and consequently in their lives. This bring us to the term of accessibility that has emerged as a way of measuring the interrelation between displacements and urban land use.

The work of Hansen (1959) was the first to present a formal concept for the term, being defined as the potential of opportunities for interaction. According to the author, "accessibility is a measurement of the spatial distribution of activities about a point, adjusted for the ability and the desire of people or firms to overcome spatial separation" (Hansen 1959, p. 73).

Thus, we have two important aspects to be considered: the first refers to the distribution of different activities and amenities in the city, and the second refers to the different desires and constraints of individuals to reach these opportunities.

Traditionally, the city center is recognized as a major provider of the city's activities and services. But as family segregation occurs, is it possible to induce the displacement of certain activities to be near the consumer families? How does the distribution of activities respond to different socioeconomic characteristics of families with a certain spatial pattern distribution?

Moreover, accessibility can be measured with respect to a variety of activities, such as jobs, schools, medical care, stores, and so on. The way that individuals evaluate their access to these different facilities is not equal. Thus, to paraphrase Weber and Kwan (2008), it is important to know for whom such access is important or relevant. 
In the residential location choice, households maximize their access to relevant spatial opportunities. The decision of households with many members becomes more complex because it involves distinct activities among the members. A household composed of two workers and two children will certainly be more interested in accessibility to jobs and schools, while a household composed of two retirees will be more interested in accessibility to amenities and their social contacts (Zondag and Pieters 2005). This can cause a loss of accessibility (e.g., of those who work, in return for better access to leisure for their children). So, how this will impact the opportunities given different household structures? These are still open questions.

A few studies explored the relation between accessibility, household composition, and residential location. Most of these studies have been conducted for the cities in developed countries in the global north considering the existence of good and publicly available datasets. Job accessibility was found to strongly influence the residential location when considered the household composition and size. Albacete (2019) when analyzing the Helsinki Capital Region (HCR) found significant differences in accessibility and residential preference by a single-person, couple without children and households with children. The results show that households with children are located in areas with worse accessibility to services than households without children. Guo and Bhat (2007) using the San Francisco Bay area for their empirical demonstration of the operationalization of the neighborhood concept applied to residential location choice, found that single-person households are located in closer proximity to regional job opportunities than other types of households. According to the authors, the shopping and recreational accessibility were not found to impact residential choice. Páez et al. (2013), investigating Toronto, compared the accessibility to jobs of single-parent households with other types of households and identified substantial differences, particularly in relation to single-parent households headed by females. Rezaei and Patterson (2018), explore the preferences of household location choice over time, considering three different time periods using census data for Montreal. The study concluded that households, in general, have a preference for areas with good job and shopping accessibility. However, the presence of children have made the households live closer to schools. These preferences have been shown to improve over time within census tracts, while housing prices and dwelling densities are becoming less important.

Other studies have focused on the household heads' workplace influence on the residential location. Srour et al. (2002) tested different accessibility measures in a household residential location model for the Dallas-Fort Worth region of Texas. The authors concluded that distances to regional central business districts and household heads' workplace strongly influenced the location predictions. In one of the few studies applied to the São Paulo Metropolitan Area, Duarte and Silveira Neto (2015) investigated how the family structure impacts on the time spent by the heads of the household in their trip to work. The results show a positive association between the number of dependents and the duration of the trip to work.

It was also explored the importance of social roles in the residential location. Pitombo (2003), investigating São Paulo city, stressed that the role of the individual is not only defined by their participation in the labor market but also relates to their marital status, gender and family situation. Among other aspects, the division of household tasks, family size and the stage in the family life cycle are pointed as important factors for the travel patterns performed by family members. In this line, the work of Schwanen et al. (2005) taking the cities in the Netherlands, hypothesize that because the residential preferences vary according to the family group, it is expected that the specific considerations of accessibility will also differ. These differences result not only in a differentiated distribution of distinct family groups over the urban and less urban space but also affect the patterns of displacement of individuals belonging to the same family group but residing in different parts of the urban area. Zondag and Pieters (2005), also studying the Netherlands, stratified the households according to its size, lifecycle of the household members, and income. The main findings were that households are less likely to move away from a more accessible location than from a less accessible location and that demographic, 
neighborhood amenities, and dwelling attributes are important variables to explain residential location choices.

This review of the literature shows the importance given to the household structure for urban spatial configuration and for trip generation in the cities, and vice versa, the spatial structure, can shed a light in the ongoing process of demographic changes (Champion 2001). Differently from most of the studies presented here, in this article we expand the accessibility analysis by considering the accessibility to a non-mandatory activity, leisure, together with accessibility to mandatory activities, jobs and education. By doing so we fill part of the gap which is fundamental to understand the potential participation of households in urban social activities that are an essential component of the building up of the Civitas, the social (and territorial) body where the urban life flows. Another contribution was to carry out this study for a large metropolitan region of the Global South, which is a region with a still limited body of work, considering that most of the literature focuses on the dynamics of household location and structure, residential choices models and travel pattern behaviors of cities in the Global North.

\section{Methodological Approach}

\subsection{Study Area}

The study area is the São Paulo Metropolitan Area (SPMA), which consists of 39 municipalities, extended through $7.946 \mathrm{~km}^{2}$, with approximately $2.200 \mathrm{~km}^{2}$ of urbanized area (Figure 1 ). The region has about 21 million inhabitants; however, the distribution of the population is fairly heterogeneous and it is strongly determined by the proximity to the city of São Paulo, which is the core city in the region. The city of São Paulo concentrates 58\% of the SPMA's total population. Together with Guarulhos, Osasco, Santo Andre and São Bernardo do Campos municipalities it adds up to a little more than $75 \%$ of the SPMA's population. This heterogeneity is linked to spatial disparities in facilities, services and work opportunities, and thus to the expected accessibility levels.

\subsection{Household Structure and Data}

To classify households, we have chosen two criteria: hierarchical position of the family member and the number of people in the family. Thus, starting from the head of the household, the other positions were defined as: partner, child or stepchild and other relatives. Five types were created, as follows:

- Single-person: individuals that live alone ${ }^{1}$.

- Couple: the householder and his or her partner, either married or unmarried.

- Nuclear: a couple with children.

- Single parent: a householder with children and no partner.

- Extended: Any of the other categories with the inclusion of other relatives that live in the household.

The nuclear, single parent and extended arrangements were subdivided according to the number of components: up to three individuals; from four to five individuals; and with more than five individuals.

Population data was extracted from the 2010 Brazilian Census, which reported a little more than six million households in the SPMA. The predominant household structure is the nuclear type (43.1\%), being $43.4 \%$ with the presence of one child, $51.1 \%$ with two or three children, and $5.5 \%$ has four or more children in the household (Figure 2).

A similar participation is observed among the other household structures, with $16.2 \%$ of extended households, $14.9 \%$ of couples, $13.2 \%$ of single parents and $12.7 \%$ of single households (Figure 2).

\footnotetext{
${ }^{1}$ Individuals living alone are not considered as family arrangements; therefore, they are treated as a "non-family" arrangement.
} 


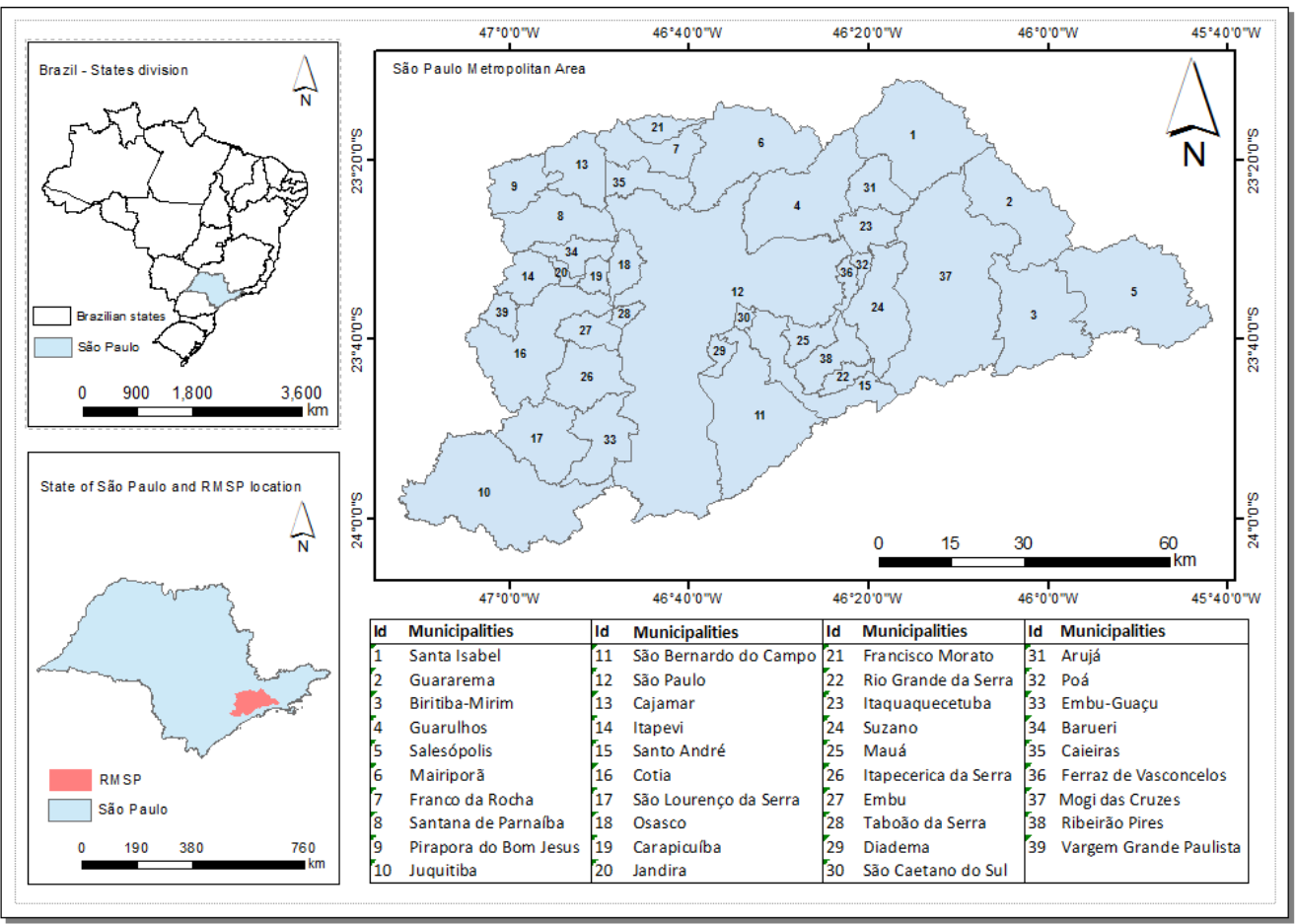

Figure 1: Research Area: São Paulo Metropolitan Area. The figures in the left indicate the location of São Paulo state and the location of the SPMA within São Paulo State. In the right figure are presented the SPMA division into municipalities. The numbers indicate the correspondent municipality of the area in the table bellow.

Table 1: Households types.

\begin{tabular}{|c|c|c|}
\hline Category name & Households & $\begin{array}{c}\text { Number of } \\
\text { members }\end{array}$ \\
\hline Single & Single & 1 \\
\hline Couple & Couple & 2 \\
\hline Nuclear-I & Nuclear & up to 3 \\
\hline Nuclear-I I & Nuclear & from 4 to 5 \\
\hline Nuclear-I I I & Nuclear & more than 5 \\
\hline SingleParent-I & Single Parent & up to 3 \\
\hline SingleParent-I I & Single Parent & from 4 to 5 \\
\hline SingleParent-III & Single Parent & more than 5 \\
\hline Extended-I & Extended & up to 3 \\
\hline Extended-I I & Extended & from 4 to 5 \\
\hline Extended-I I I & Extended & more than 5 \\
\hline
\end{tabular}

According to size, most of single parent and extended households have up to three members. Although households with more than five members have a minor representation, it is important to look into them given their complexity. We also believe that because of the size, they have difficulty finding a desirable place, with a proper space, in the city center and this could restrict their access to the amenities.

To provide a better overview of the relationship between household types and accessibility, we initially explore the location pattern of different household structures within the SPMA to further 
investigate how it influences their accessibility. In Figure 3 we spatialize the major groups in rate per 1000 households in census weighting areas using a quantile-based classification.

Single and Couple households tend to live in the center of the city. The CDB holds most of the city life activities that could attract this type of household to live there or nearby. These places also have a higher price per square meter, which is more likely to attract smaller households that have less demand for space. Despite the similar concentration of Single and Couple households, it can be noted that Couples have higher dispersion over the area, where the fifth quintile of the distribution also appears in the north and the east side of SPMA. According to Jung and Yang (2016) the phases of formation in the household can influence where they live. Just-married and young-married households tend to reside in temporary homes in the center; however, the expectation to raise children encourages them to settle in suburbia. In the particular case of a developing country like Brazil, this pattern may be also related to socioeconomic conditions. While Couple households can be characterized by a broader range of socioeconomic conditions, including those that can only afford to live in peripheral areas of the metropolis, Single households are characterized by higher levels of income.

In contrast, central areas of SPMA posses the first quintile of the distribution of Nuclear and Single Parent households. The choice of living in peripheral areas may have different meanings in a metropolitan region like São Paulo, whose process of production of urban space is strongly marked by the exclusion of the poorest. Meanwhile, high-income households with children often consider central areas as inadequate in terms of peaceful and ample space and decide to live in the suburbs, mainly in gated communities (Caldeira 2000). This choice may cause a loss of accessibility to jobs to parents. However, poorer households - which are often larger-are more likely to occupy peripheral areas characterized by precarious housing, including slums and irregular settlements.

Despite a high presence of extended households in the East Zone of SPMA, their spatial pattern is more heterogeneous (Figure 3). They often represent multigenerational households, which have become more common with the increase in life expectancy, decrease in fertility, and increase in divorces and children born outside marriage (Alves and Cavenaghi 2016). Nevertheless, while this household structure may be the result of a family choice, it has been also pointed out as an important facet of the Brazilian housing deficit (Lima Neto et al. 2013). Difficulties in accessing home loans and the high prices of dwellings in comparison with household incomes are examples of situations that often motivate this type of household structure.

The analysis reveals a close link between household income and its size and composition. In Figure 4 we present the distribution of our household types in relation to income levels in units of minimum wage per capita. As the number of household members grow they tend to concentrate in the lower income level (up to one minimal wage per capita. That is an expected trend since the number of dependents with respect to the number of working household members is one of the main components to affect inequality in the distribution of household income per capita (Wajnman et al. 2006). Moreover, we can see that this pattern is less accentuated in extended households since more working adults can be part of the household. So, cohabitation can be a strategic decision to reduce the individual share of fixed living costs and hence contributes to a higher level of household income.

However, studies such as Leone et al. (2010); Ribeiro et al. (2019); Wajnman et al. (2006), that analyze the distribution of household income inequality in Brazil, show that other factors besides dependency can contribute to disparities. Characteristics such as the age and gender of the head of household can also impact the household income per capita. Thus, the low income levels observed in the SingleParent households (Figure 4) may be related to the fact that they are often headed by women and youth.

Although Figure 3 only shows the major household groups, our analyses also revealed a clear relationship between family size and CBD distance, with larger families located farther from the center.

These different patterns of distribution can cause distinct demands and change the type of housing that is expected to be constructed in the areas of the city. The Housing Union Report already pictures this difference in the constructive pattern, finding that: "There is a strong preference for tra- 
ditional 2-bedroom properties in other cities of SPMA, unlike the city of São Paulo, where 1-bedroom properties have more significant participation in launches" (SECOVISP 2018, p. 66). In addition, the development of 1-bedroom houses was concentrated in the CBD of São Paulo city. The response of the housing market may segregate the household structures even further. Consequently, our major concern is whether these patterns can cause different levels of accessibility among the households structures. This is the question that we will try to answer in the remaining of the paper.

Figure 2: Distribution of households structures in the SPMA, 2010.

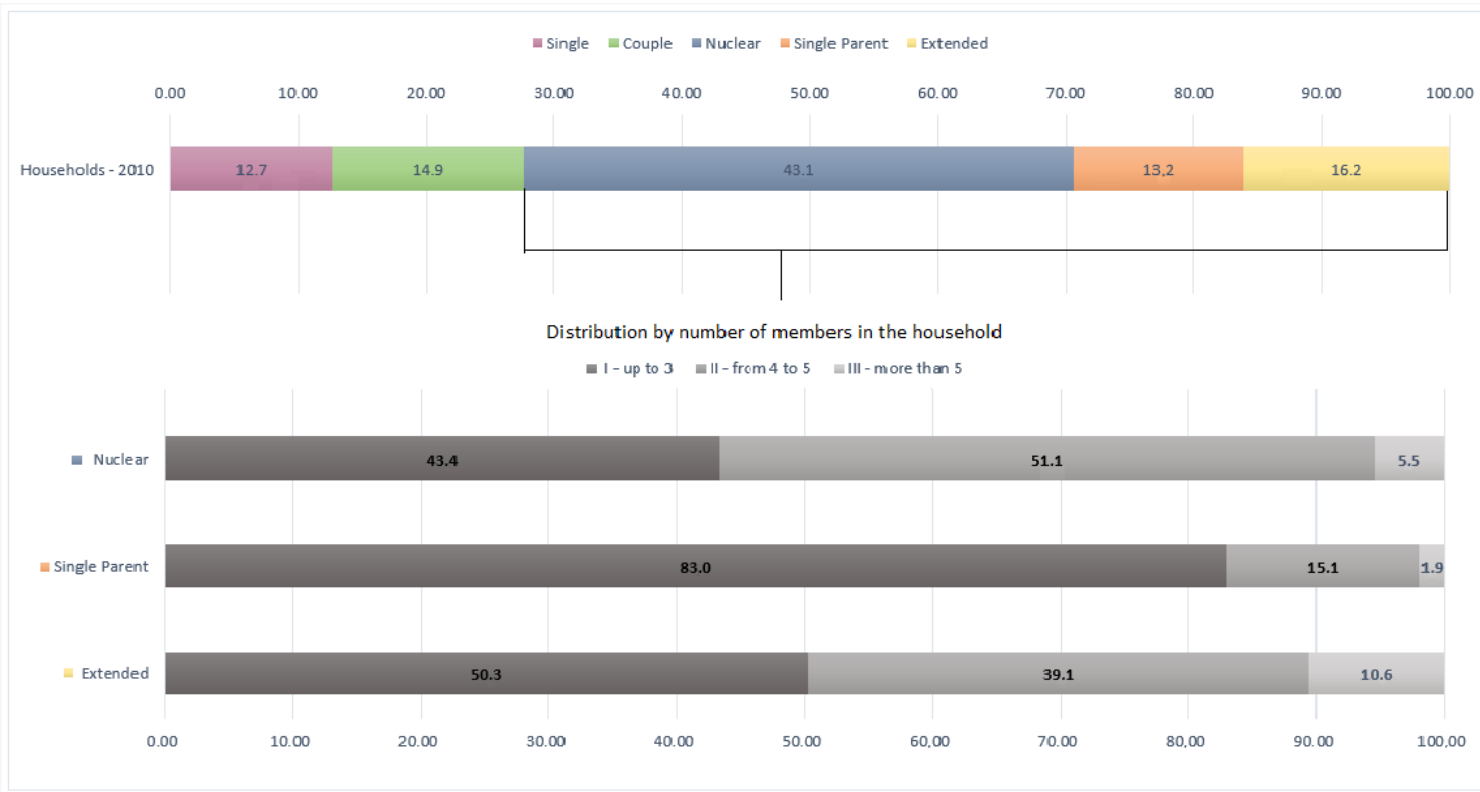

Several databases were used to calculate the accessibility index. Data on the distribution of formal jobs was obtained from the 2013 Annual Report of Social Information (RAIS), elaborated by the Ministry of Labor and Employment (Ministry of Labor and Employment 2013). We maintained at the base the establishments that declared to have five or more active jobs. Through ZIP code information, it was possible to georeference the companies in the areas.

One limitation is that this database covers only formal jobs. The SPMA, as in other large urban centers in Latin America, count on a large number of informal jobs. Although the rates of informality in SPMA decreased from 2000 to 2010, it was estimated at 23 percent in 2010 (Brazilian Institute of Geography and Statistics 2010). Some studies were conducted to analyze accessibility and informality in SPMA (Boisjoly et al. 2017; Moreno-Monroy and Ramos 2020), but, unfortunately, there is no official and systematic database available on informal jobs.

The georeferenced data of schools was obtained from the Center for Metropolitan Studies (CEM), reference year of 2013, from which we extracted the location of public and private units (daycare and preschool units, elementary schools and high schools) (Center for Metropolitan Studies 2013). Finally, the distribution of leisure amenities was extracted from the 2011 Land Use and Occupation Map, prepared by São Paulo Metropolitan Planning Company (Paulista Company of Metropolitan Planning 2010). We extracted the areas classified as: 1) cultural sites (including theaters, cultural centers, libraries and museums); 2) sports and recreational areas (including clubs, sports gym, soccer fields, fishing places, and racecourse); and 3) parks, squares and green areas.

In addition to the amenities, the accessibility index needs a street dataset to measure the possible trips to interest points. This data was obtained from the Center for Metropolitan Studies, last updated in 2016 (Center for Metropolitan Studies 2016). We also used data from the 2007 Origin and Destination Survey, usually called the OD Survey, performed by the São Paulo Metropolitan Company 
Figure 3: Spatial distribution of households structures in the SPMA, 2010.
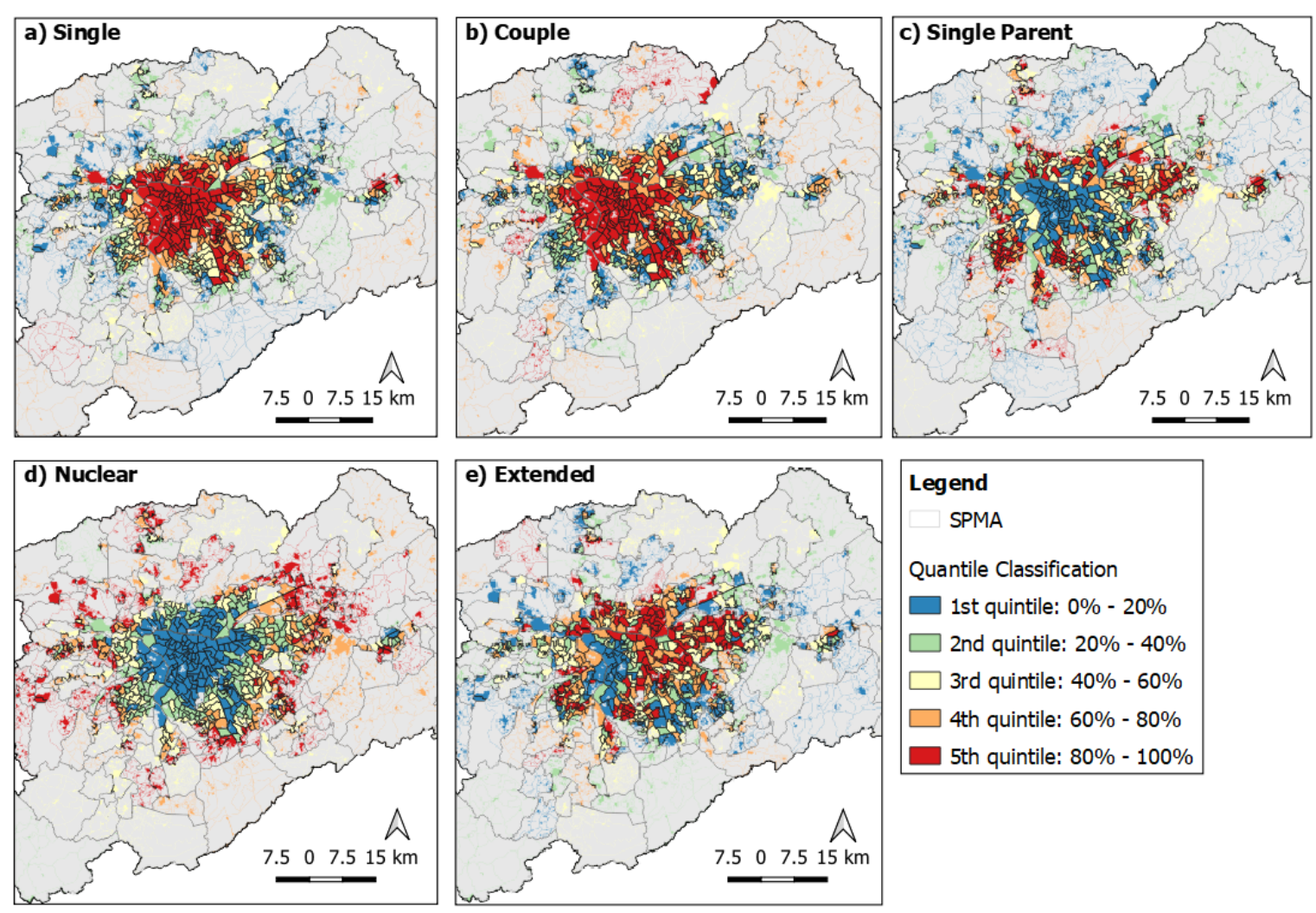

Figure 4: Distribution of households structures by income level in the SPMA, 2010.

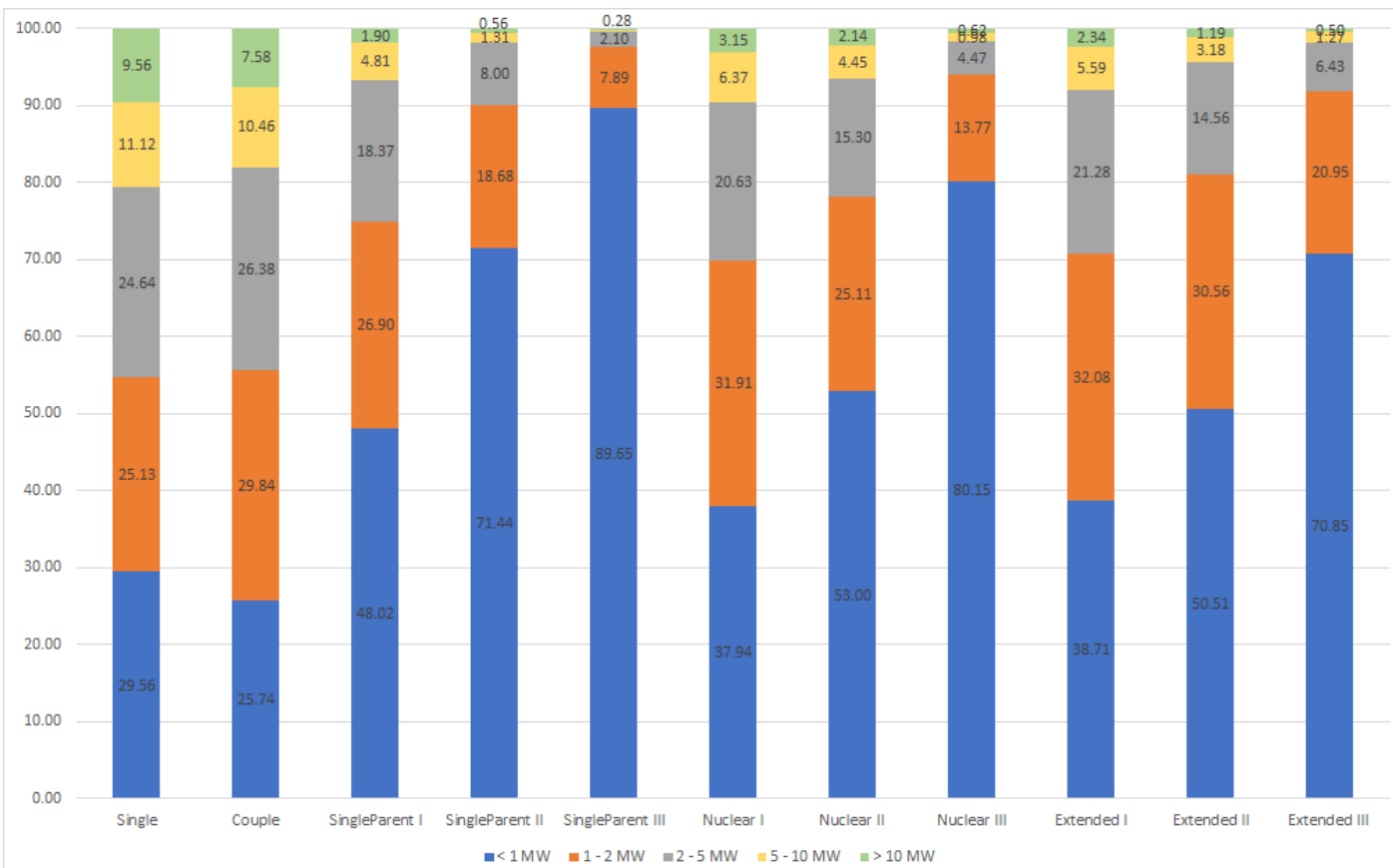

MW - Minimal Wage. The value of minimal wage in 2010 was 510 Brazilian Reais, equivalent to 289,95 USD. Data from Brazil Demographic Census, 2010. 
(Companhia do Metropolitano de São Paulo 2007). This database served as a way to observe the travel behavior of families.

\subsection{Accessibility Index}

This study uses the gravitational model as a metric for the accessibility index. This is a widely used accessibility measure that has the interesting feature of adding together the opportunities available in specific zone, weighted by a function of the difficulty of reaching that zone. Consequently, this feature and the availability of data makes this index adequate to represent what this work seeks to investigate. A general formulation of the model can be represented as:

$$
A_{i}=\sum_{j} W_{j} f\left(C_{i j}\right)
$$

where $A_{i}$ is the accessibility of individuals in the point $i$ for a given type of opportunity; $W_{j}$ is the number of opportunities at area $j$; and $f\left(C_{i j}\right)$ is an impedance function for trips between $i$ and $j$, associated to a cost of displacement $C$ that could be measured by distance, time or monetary cost. We use the travel time from each centroid to a given weighting area to all other weighting areas as a displacement cost, calculating by the fastest route in Network Analysis Tool, on ArcGIS 10.1 software ${ }^{2}$.

As argued by Owen and Levinson (2015), the specification of the impedance function may have a huge impact on the result of the accessibility index, and the functions with the best performance are estimated independently in each specific case. In this manner, we define the impedance function based on the observed behavior of the travel times and volume of interactions in the Origin-Destination (OD) database, for three types of travel purpose: Work, Education and Leisure. In self-declaration researches, individuals tend to round up their response. To avoid the problem arising from this behavior, we grouped the travel time in intervals of five minutes and observed the number of individuals that complete their trip in these ranges. The procedure is explained in more detail in the next section.

Based on the functions used in the literature (Reggiani et al. 2011), we analyze which line fits better to the data, observing the standard deviation of the residuals about the regression line. The results are shown in Table 2.

Table 2: Estimated results of the impedance functions for the trip to work, to education and to leisure

\begin{tabular}{lllll}
\hline Impedance Function & Math Specification & Job & Education & Leisure \\
\hline Power-decay & $f\left(t_{i j}\right)=t_{i j}^{-y}$ & 0.3225 & 0.3250 & 0.2923 \\
NE $^{1}$ & $f\left(t_{i j}\right)=\exp \left(-\beta_{1} \cdot t_{i j}\right)$ & 0.5821 & 0.5937 & 0.5650 \\
Log-normal NE & $f\left(t_{i j}\right)=\exp \left(-\beta_{1} \cdot \log \left(t_{i j}^{2}\right)\right)$ & 0.3225 & 0.3250 & 0.3041 \\
Norma 1 NE & $f\left(t_{i j}\right)=\exp \left(-\beta_{1} \cdot t_{i j}^{2}\right)$ & 0.6308 & 0.6712 & 0.6272 \\
Square-root NE & $f\left(t_{i j}\right)=\exp \left(-\beta_{1} \cdot \sqrt{t_{i j}}\right)$ & 0.4890 & 0.4940 & 0.4593 \\
Generalized NE & $f\left(t_{i j}\right)=\exp \left(-\beta_{1} \cdot t_{i j} \beta_{2}\right)$ & 0.6320 & 0.6965 & 0.6473 \\
\hline
\end{tabular}

${ }^{1} \mathrm{NE}$ - negative exponential.

Among the functions proposed by the literature, the value of $R^{2}$ shows that the Normal Exponential Negative function is the one that best fits the data for the three considered trip purposes. Thus, by generalizing this function and letting different values for $\beta_{2}$ be estimated, we were able to slightly

\footnotetext{
${ }^{2}$ The adoption of this procedure is due to the limited resources available. For validation, 99 travel pairs were randomly selected and compared with time travel estimated in Google Maps during free traffic time. The analysis consisted of a paired ttest, with the null hypothesis of equality of mean. The result shows that the null hypothesis is not rejected with 95 confidence. Hence, we can consider the equality between the Google Maps API Travel Time Matrix and the one generated by Arcgis, Network Analysis Tool.
} 
improve the fit to the data. Thus, the Generalised Negative Exponential function will represent the impedance function and our final accessibility index is given by Equation 2 for the three trip purposes.

$$
A_{i}^{k}=\sum_{j} W_{j}^{k} \exp \left(-\beta_{1} \cdot t_{i j}^{\beta_{2}}\right)
$$

Once the impedance function was defined, the next step is setting the associated parameters that best fit the observed data. From a linear regression analysis, the parameters were estimated for each type of trip (Table 2). The curves of the respective functions for work, education and leisure can be observed in Figure 5. The functions have the characteristics of: i) being flattened at the top; ii) have a soft decay; and iii) tend to zero at infinity. These three characteristics are pointed out by Ingram (1971) as desirable characteristics for a function of the degree of accessibility.

Table 3: Parameters values for the impedance function by trip purpose

\begin{tabular}{lll}
\hline Trip Purpose & $\beta_{1}$ & $\beta_{2}$ \\
\hline Work & 0.0019 & 2.3 \\
Education & 0.0001119 & 4.272 \\
Leisure & 0.0004038 & 3.329 \\
\hline
\end{tabular}

Figure 5: Generalized negative exponential function estimated for travel times to jobs, education and leisure.

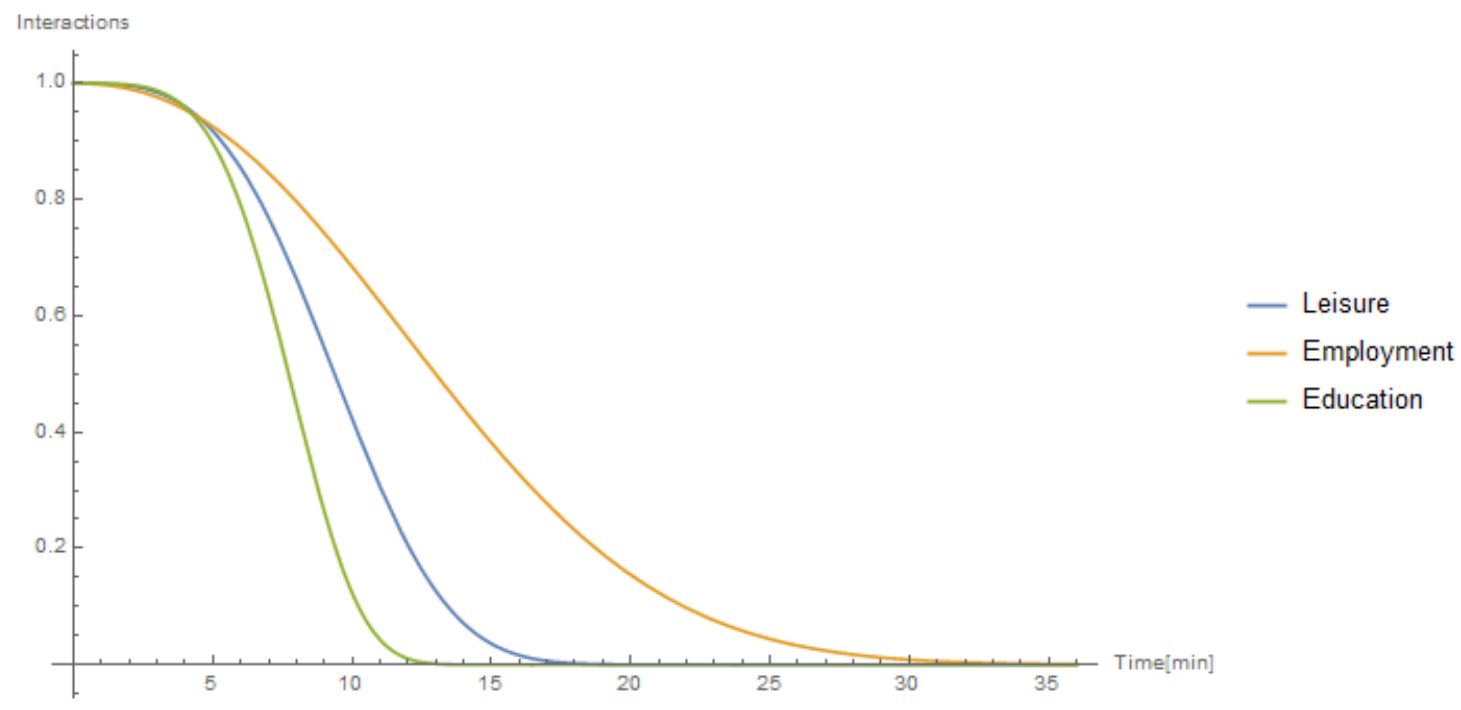

To analyze accessibility from the perspective of households, the indicators of Equation 2 are weighted by the distribution of a particular household arrangement $\left(P_{b}\right)$ in the region.

$$
A_{b}^{k}=\sum_{i} P_{i b} \cdot A_{i}^{k}
$$

with $h=1,2, \ldots, 11$, for each type of household composition defined above. The result gives the general accessibility for an amenity $k$ of a particular household composition $b$ in the SPMA. 
Taking the ratio between the accessibility indexes in Equation 4, we have a relative accessibility indicator (RAI) for the households and we are able to compare the accessibility through the different household compositions.

$$
R A I_{p q}^{k}=\frac{A_{p}^{k}}{A_{q}^{k}}
$$

$A_{p}^{k}$ is the general accessibility of a household of type $p$ to facilities of type $k$; and $A_{q}^{k}$ is the general accessibility of a household of type $q$ to facilities of type $k$.

A similar indicator was proposed by Páez et al. (2010). The relative accessibility deprivation indicator (RADI), takes the form of a ratio of two cumulative opportunities accessibility indexes. However, in the RADI the threshold varies with the type of household $(p)$ and its residential location $(i)$. Thus, Páez et al. (2010) can estimate the differences between groups within the area. However, in our case, the result cannot be used to compare household accessibility between areas and it instead produces a general result for the whole region.

\section{Results and Discussion}

The results for accessibility to jobs, education and leisure are presented in Figures 6,7 and 8, respectively. The accessibility values measured for each travel purpose were normalized to a range of 0 to 1 and divided into deciles. In addition, the outliers of job and education identified were treated separately and were not included in the normalization.

The highest levels of accessibility to jobs are found in the center of the SPMA and the lowest levels in the border areas, with a regular concentric shape. Accessibility to education and leisure presents a less clear pattern, with areas of high and low accessibility mixing throughout the SPMA.

Another important factor to note here is the discrepancy between the accessibility values presented in each area. Figure 9 shows the frequency of the index values. It would be desirable to observe no preponderance of areas with very low accessibility. However, in the index of accessibility to jobs we have a large number of areas in the range of 0 to 0.1 . With an average of 0.13 , the index has a high standard deviation of 0.17 .

The index of accessibility to leisure presents a similar concentration pattern, although not with the same intensity. About 38 of the areas are in the range of 0 to 0.1 and 84 of the areas have indices below 0.3 . We verified a large number of areas with low indexes with very few areas with high indexes, which reflects on a low average of 0.18 and a high standard deviation of 0.16 .

Accessibility to basic education has the best distribution in the region. Despite the low concentration indexes, we find that 84 of areas are in the range of 0 to 0.4 , indicating a better distribution than the previous cases.

These results show that there are regions with high accessibility, well above the other areas. It remains now to analyze which groups of families reside in these areas and to determine if there is an association between household composition and the observed accessibility. Due to its nonparametric nature, the Spearman rank-order correlation coefficient was used to measure such association (Table 4).

The results reveal a deep inequality of accessibility to jobs among household types, as their correlation measures presented the widest range of significant coefficient, from 0.7 (Single) to - 0.41 (NuclearIII). The measures concerning accessibility to education suggest a less unequal distribution, since the correlation coefficients were positive and significant for most household types, except for Nuclear-III and SingleParent-III.

While Singles, Couples and Extended-I presented the highest positive correlation coefficients with accessibility to jobs, education and leisure, Nuclear-III and SingleParent-III showed the most 
Figure 6: Potential accessibility to jobs, SPMA. The map shows the normalized potential accessibility to jobs, estimated with an exponential shaped function and divided into decil.

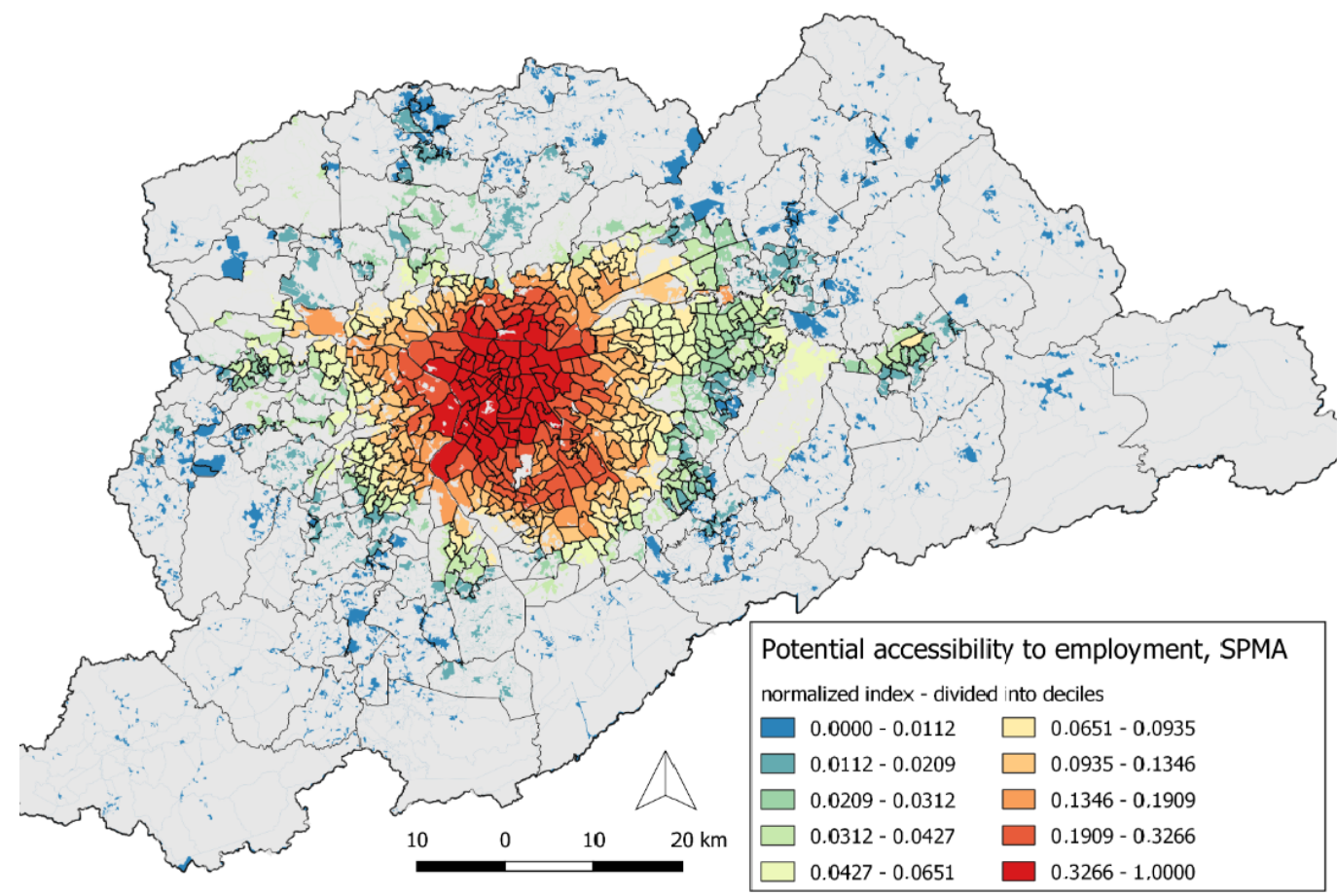

Figure 7: Potential accessibility to education, SPMA. The map shows the normalized potential accessibility to education, estimated with an exponential shaped function and divided into decil.

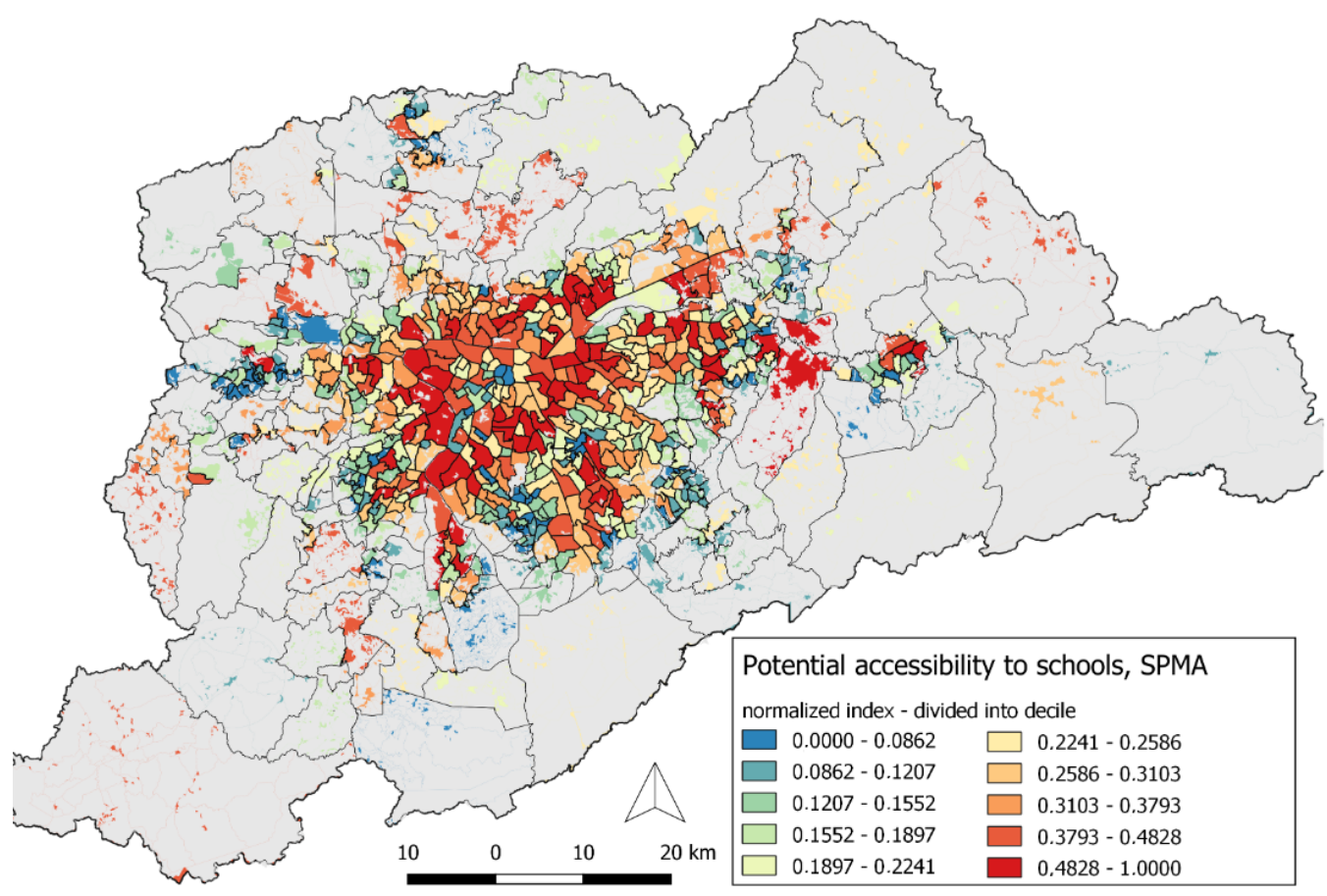


Figure 8: Potential accessibility to leisure, SPMA. The map shows the normalized potential accessibility to leisure, estimated with an exponential shaped function and divided into decil.

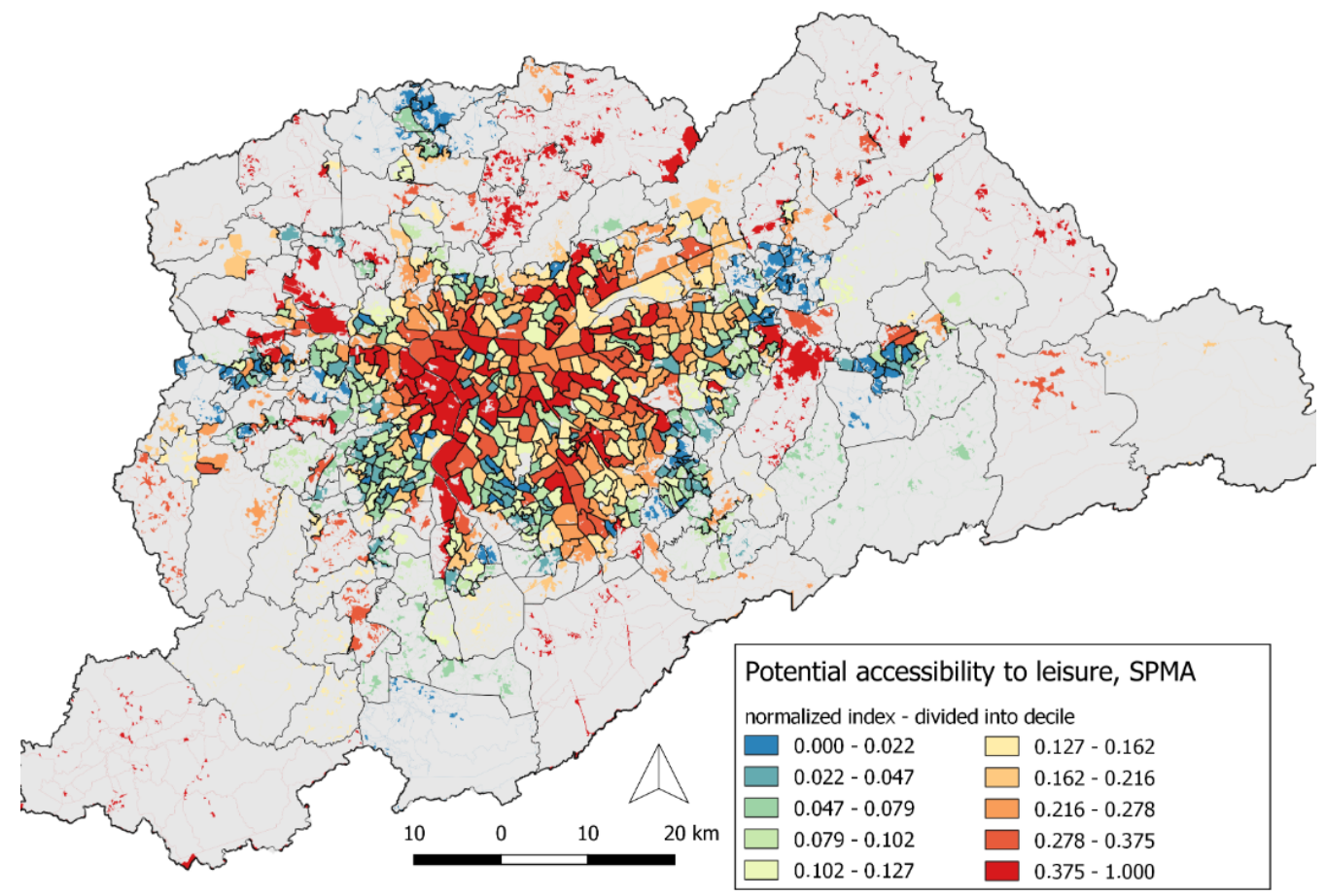

Figure 9: Frequency of accessibility indexes.

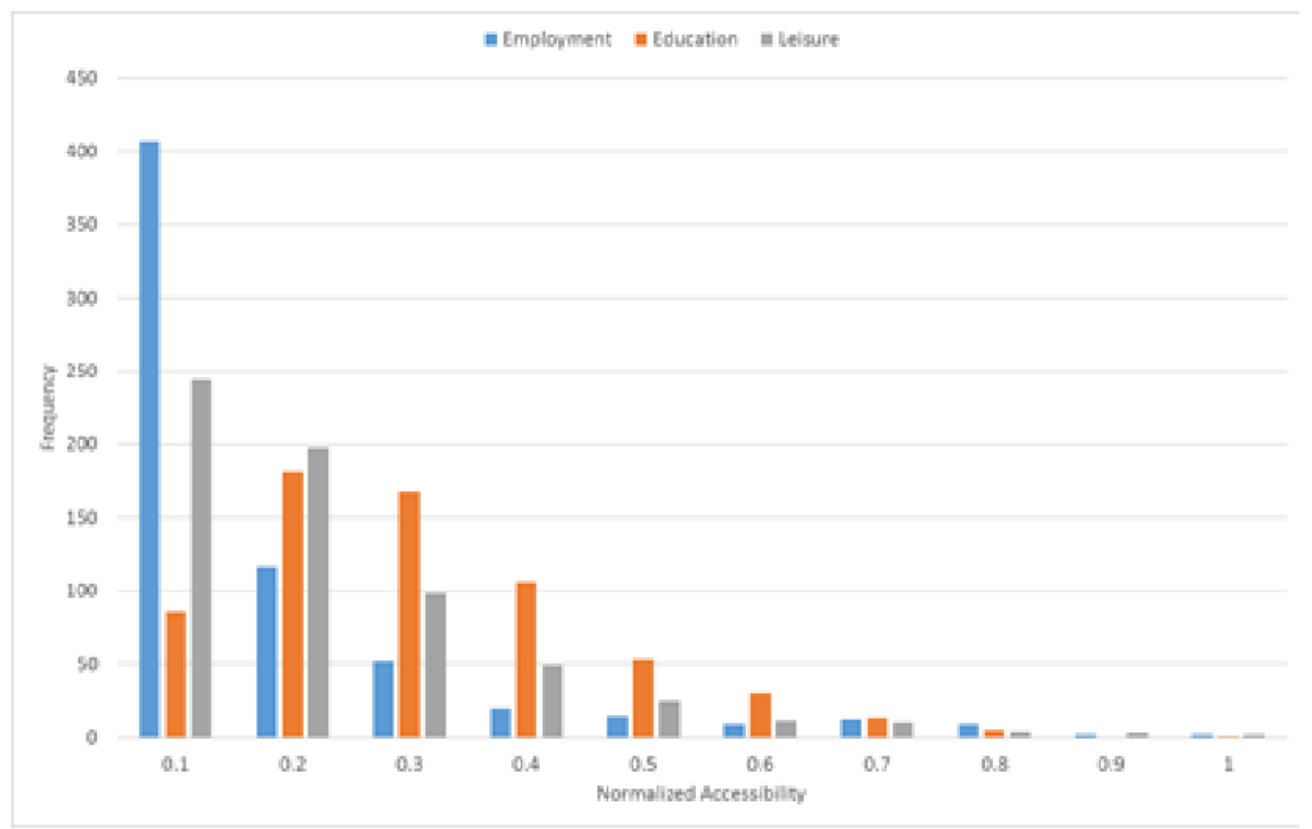


disadvantageous results, with negative or non-significant correlation between their presence and the accessibility indicators.

Table 4: Spearman Correlation between accessibility and household types.

\begin{tabular}{|c|c|c|c|}
\hline Households & Jobs & Education & Leisure \\
\hline Single & $0.696^{*}$ & $0.589^{*}$ & $0.429^{*}$ \\
\hline Couple & $0.608^{*}$ & $0.640^{*}$ & $0.480^{*}$ \\
\hline Nuclear-I & $0.287^{*}$ & $0.560^{*}$ & $0.355^{*}$ \\
\hline Nuclear-I I & $0.091^{* *}$ & $0.458^{*}$ & $0.268^{*}$ \\
\hline Nuclear-I I I & $-0.407^{*}$ & - & $-0.087^{* *}$ \\
\hline SingleParent-I & $0.418^{*}$ & $0.541^{*}$ & $0.336^{*}$ \\
\hline SingleParent-II & $-0.106^{*}$ & $0.165^{*}$ & - \\
\hline SingleParent-III & $-0.318^{*}$ & - & $-0.156^{*}$ \\
\hline Extended-I & $0.616^{*}$ & $0.570^{*}$ & $0.420^{*}$ \\
\hline Extended-I I & $0.260^{*}$ & $0.482^{*}$ & $0.315^{*}$ \\
\hline Extended-I I I & $-0.085^{* *}$ & $0.201^{*}$ & $0.104^{*}$ \\
\hline
\end{tabular}

We now turn to the question of the accessibility differential levels among household composition in jobs, education and leisure. Our comparison relies on the analysis of the ratio of the overall accessibility faced by the groups in the SPMA, defined in Equation 4. If the value of the RAI is equal to 1 , we have parity between the groups; values greater than 1 indicate that the group in the numerator has access to more facilities of the type $k$ than the group in denominator; the opposite happens if the RAI's value is lesser than 1 .

Figures 10, 11 and 12 show the comparison matrix among household types to accessibility to jobs, education and leisure, respectively. Cells marked in yellow represent that the households are indistinguishable (RAI value from 0.96 to 1.04 ); cells in green indicate that the household in the column have a lower accessibility level in relation to the household in the row; meanwhile, cells in orange represent a higher accessibility to the household in the column in relation to the household in the row. We also highlight in red the RAIs that have values greater than 2, displaying a wide disparity.

For the accessibility to job, Single households experience relatively high levels. Comparing it to households of type SingleParent-II, SingleParent-III, Nuclear-III and Extended-III, the RAI is higher than 2, which indicates that Single households have access to more than two times as many jobs than these households.

The Couple and Extended-I households also present a superior relative RAI with respect to the other households, except in the case of Single households. It is noteworthy that job deprivation occurs for households with more members, which is aligned with the negative correlation that was found previously.

The RAI for accessibility to education does not vary too much among households. As we can see in the matrix of Figure 11, many cells are market in yellow. Nonetheless, the values of all others cells do not stay too far from 1. However, low RAIs are present for SingleParent-II, SingleParent-III and Nuclear-III households.

For accessibility to leisure there is also no great disparity between households (Figure 12). Meanwhile, a relative superiority of access to leisure areas is observed for Single, Couple and Extended-I households. Again, SingleParent-II, SingleParent-III and Nuclear-III households have the lowest RAI.

The analysis of the three RAI indexes seems to show that family size exerts an important influence, decreasing the accessibility level the greater the number of members in the household. As mentioned by Fujita (1989), places with good accessibility demand a high price for space. This could be the case of areas with good accessibility in the SPMA, implying in a trade-off for households that require large dwellings. 
The composition of the household also has an impact, with the SingleParent group being the most deprived and Single household being the most privileged.

In Section 3.2 we showed a spatial concentration of single households in the center of SPMA. The center of the SPMA has a high concentration of jobs, education and leisure in most of the areas. In this way, single households have, in general, better access to a set of facilities due to their choice of living near the city center. In addition, because this is a residence of only one member, they can live in smaller spaces as a way to afford the higher prices in the area. To better understand these results an analysis of the housing market and the factors that influence the residential location choice of these households becomes necessary.

Also, if we look at the household with the same number of members, the results show that Extended households present superiority in accessibility to their counterparts in size. The result may indicate a strategy for families that strengthen them, allowing to cooperate and live in places with better accessibility compared to others.

Figure 10: RAI to jobs by household type.

\begin{tabular}{|c|c|c|c|c|c|c|c|c|c|c|c|}
\hline $\begin{array}{l}\text { Household } \\
\text { Types }\end{array}$ & Single & Couple & $\begin{array}{c}\text { Single Parent } \\
\mathrm{I}\end{array}$ & \begin{tabular}{|c|} 
Single Parent \\
II
\end{tabular} & \begin{tabular}{|c|} 
Single Parent \\
III
\end{tabular} & Nuclear I & Nuclear II & Nuclear III & \begin{tabular}{|c|} 
Extended \\
1 \\
\end{tabular} & $\begin{array}{c}\text { Extended } \\
\text { II }\end{array}$ & $\begin{array}{c}\text { Extended } \\
\text { III }\end{array}$ \\
\hline Couple & 1.33 & 1.00 & 0.82 & 0.62 & 0.47 & 0.76 & 0.69 & 0.52 & 0.99 & 0.75 & 0.63 \\
\hline Single Parent II & 2.14 & 1.61 & 1.33 & 1.00 & 0.75 & 1.22 & 1.12 & 0.84 & 1.60 & 1.22 & 1.01 \\
\hline Single Parent III & 2.84 & 2.14 & 1.77 & 1.33 & 1.00 & 1.62 & 1.49 & 1.11 & 2.12 & 1.61 & 1.34 \\
\hline Nuclear III & 2.55 & 1.92 & 1.59 & 1.19 & 0.90 & 1.46 & 1.34 & 1.00 & 1.90 & 1.45 & 1.21 \\
\hline Extended I & 1.34 & 1.01 & 0.83 & 0.63 & 0.47 & 0.77 & 0.70 & 0.53 & 1.00 & 0.76 & 0.63 \\
\hline Extended II & 1.76 & 1.33 & 1.09 & 0.82 & 0.62 & 1.01 & 0.92 & 0.69 & 1.31 & 1.00 & 0.83 \\
\hline Extended III & 2.12 & 1.59 & 1.31 & 0.99 & 0.74 & 1.21 & 1.11 & 0.83 & 1.58 & 1.20 & 1.00 \\
\hline
\end{tabular}

Figure 11: RAI to education by household type.

\begin{tabular}{|c|c|c|c|c|c|c|c|c|c|c|c|}
\hline $\begin{array}{c}\text { Household } \\
\text { Types }\end{array}$ & Single & Couple & $\begin{array}{c}\text { Single Parent } \\
\mathrm{I}\end{array}$ & \begin{tabular}{|c|} 
Single Parent \\
II
\end{tabular} & \begin{tabular}{|c|} 
Single Parent \\
III
\end{tabular} & Nuclear I & Nuclear II & Nuclear III & \begin{tabular}{|c|} 
Extended \\
1
\end{tabular} & $\begin{array}{c}\text { Extended } \\
\text { II }\end{array}$ & $\begin{array}{c}\text { Extended } \\
\text { III }\end{array}$ \\
\hline Single & 1.00 & 1.02 & \begin{tabular}{|l|}
0.99 \\
\end{tabular} & \begin{tabular}{|l|}
0.92 \\
\end{tabular} & 0.88 & 0.98 & 0.97 & 0.90 & \begin{tabular}{|l|}
1.00 \\
\end{tabular} & 0.98 & 0.94 \\
\hline Couple & 0.98 & 1.00 & 0.97 & 0.91 & 0.87 & 0.96 & 0.95 & 0.89 & 0.98 & 0.96 & 0.92 \\
\hline Single Parent II & 1.08 & 1.10 & 1.07 & 1.00 & 0.96 & 1.06 & 1.05 & 0.98 & 1.09 & 1.06 & 1.02 \\
\hline Single Parent III & 1.13 & 1.15 & 1.11 & 1.05 & 1.00 & 1.11 & 1.09 & 1.02 & 1.13 & 1.11 & 1.07 \\
\hline Nuclear III & 1.11 & 1.13 & 1.09 & 1.02 & 0.98 & 1.09 & 1.07 & 1.00 & 1.11 & 1.09 & 1.04 \\
\hline Extended I & 1.00 & 1.02 & 0.98 & 0.92 & 0.88 & 0.98 & 0.96 & 0.90 & 1.00 & 0.98 & 0.94 \\
\hline Extended II & 1.02 & 1.04 & 1.00 & 0.94 & 0.90 & 1.00 & 0.98 & 0.92 & 1.02 & 1.00 & 0.96 \\
\hline Extended III & 1.06 & 1.08 & 1.05 & 0.98 & 0.94 & 1.04 & 1.03 & 0.96 & 1.07 & 1.04 & 1.00 \\
\hline
\end{tabular}

\section{Conclusions}

The household structure has been pointed in the literature as an important element to shape housing location. Considering 11 types of households' groups, separated according to the position occupied by their members and by the number of individuals, we confirm that SPMA presents clear spatial patterns in the residential location of these different household groups.

The same pattern describe by Jung and Yang (2016), and Ferrari et al. (2019) was found, with Single and Couple households more common in the central area and the Nuclear and Single Parent 
Figure 12: RAI to leisure by household type.

\begin{tabular}{|c|c|c|c|c|c|c|c|c|c|c|c|}
\hline $\begin{array}{c}\text { Household } \\
\text { Types }\end{array}$ & Single & Couple & $\begin{array}{c}\text { Single Parent } \\
\text { । }\end{array}$ & $\begin{array}{c}\text { Single Parent } \\
\text { II }\end{array}$ & $\begin{array}{c}\text { Single Parent } \\
\text { III }\end{array}$ & Nuclear I & Nuclear II & Nuclear III & \begin{tabular}{|c|} 
Extended \\
1 \\
\end{tabular} & $\begin{array}{c}\text { Extended } \\
\text { II }\end{array}$ & $\begin{array}{c}\text { Extended } \\
\text { III }\end{array}$ \\
\hline Single & 1.00 & 1.02 & 0.94 & 0.86 & 0.77 & 0.94 & 0.93 & 0.84 & \begin{tabular}{|l|}
0.98 \\
\end{tabular} & 0.93 & 0.89 \\
\hline Couple & 0.99 & 1.00 & 0.93 & 0.85 & 0.76 & 0.93 & 0.92 & 0.82 & 0.96 & 0.92 & 0.87 \\
\hline Single Parent II & 1.16 & 1.18 & 1.10 & 1.00 & 0.90 & 1.10 & 1.08 & 0.97 & 1.13 & 1.08 & 1.03 \\
\hline Single Parent III & 1.29 & 1.31 & 1.22 & 1.11 & 1.00 & 1.22 & 1.20 & 1.08 & 1.26 & 1.20 & 1.15 \\
\hline Nuclear III & 1.20 & 1.21 & 1.13 & 1.03 & 0.93 & 1.13 & 1.11 & 1.00 & 1.17 & 1.12 & 1.06 \\
\hline Extended I & 1.03 & 1.04 & 0.97 & 0.88 & 0.79 & 0.97 & 0.95 & 0.86 & 1.00 & 0.96 & 0.91 \\
\hline Extended II & 1.07 & 1.09 & 1.01 & 0.92 & 0.83 & 1.01 & 1.00 & 0.90 & 1.04 & 1.00 & 0.95 \\
\hline Extended III & 1.13 & 1.14 & 1.06 & 0.97 & 0.87 & 1.06 & 1.04 & 0.94 & 1.10 & 1.05 & 1.00 \\
\hline
\end{tabular}

households living in peripheral areas. The size, related to the presence of children, plays an important aspect in the configuration; as the larger the family, the further away from the city center they tend to be located.

The meaning and implications of such spatial outcome is closely related to the local context and opens a range of desirable studies for the area. Our main interest was to understand how this spatial configuration could give rise to differentials in terms of urban life and opportunities. To investigate this, we sought to analyze the differences in accessibility among the households' groups.

The gravitational accessibility index estimated the job, education and leisure accessibility to each weighting area of the SPMA. The results point to a high disparity between accessibility levels in the region. Accessibility to jobs has its highest levels concentrated in the central area, meanwhile leisure and education present a less clear pattern, but their dispersion between areas is also quite high. The most worrisome conditions are found in the north, which displays the lowest accessibility indexes.

The Spearman's coefficient reveals a deep inequality to job accessibility between household types and a less unequal distribution for education activities.

The accessibility index was weighted by the distribution of household types and the ratio allows a comparison to be made between the different households. The RAI ratios confirm the large differences in accessibility to jobs between the household types, with Single, Couple and Extended-I households being the most favored. The most worrisome situation occurs in relation to household types SingleParent-II, SingleParent-III and Nuclear-III, which always presented the worst conditions in comparison with other groups. This result should be further investigated since it suggests the exclusion of these groups from places with better opportunities. This is important because single-parenting has been growing relative to other household types in the last decades.

The contrast between the levels of accessibility of single-parent and extended households raise discussion about the role of family cohabitation in the country. Family cohabitation represents one of the main components of the Brazilian housing deficit, constituting approximately $30 \%$ of the $5,572,700$ urban households in housing deficit conditions (Fundação João Pinheiro 2018). Nevertheless, this study shows that family cohabitation represents, in fact, an important survival strategy for poor families, with positive impacts on their accessibility to different activities. Such result corroborates criticisms of the official housing deficit statistics (Alves and Cavenaghi 2016) which argue that family cohabitation does not represent a disadvantage in itself.

The number of family members was a crucial factor in determining the level of accessibility among households. In the three cases that we observed, the RAI decreases as the number of members in the family increases. This result suggests the existence of a trade-off between space and accessibility as stated by Beckmann (1973). However, Ferrari et al. (2019) shows that the movement of bigger families to the borders of São Paulo city was not translate in gains of house space and it was closely related to a decrease in household income. Therefore, this condition if often related to an accumulation 
of disadvantages in precarious areas at the outskirts of the metropolis. In the city of São Paulo, it was found that low job accessibility areas, which are located predominantly on the periphery of the municipality, are associated with worse socioeconomic conditions, shorter life expectancy, lower HDI and precarious infrastructure (Slovic et al. 2019).

The integration of transport and housing policies have an important role in the urbanization process. The characteristics of households' arrangements and its interaction with the accessibility to different facilities is fundamental in the assessment of the use of the urban space and the pace and quality of the on-progress urbanization. Our results raise questions about the relationship between the changes in household structure that occurred over the last decade, the dynamics of the real estate market and the production of the urban space. In relation to the first point, important changes that can have impact on accessibility and residential choice are the fall in the average household size, the fall in the number of traditional-family households and the increasing proportion of single-person and single-parent households (Cavenaghi and Alves 2012; Champion 2001).

The difference in the accessibility levels among household types are related to the heterogeneity of their spatial distribution. It demonstrates the importance of integrated transport and housing policies to consider the housing demands of different household types. Thus, for future studies it would be interesting to: 1) investigate the dynamics of the housing market related to the variation of price and size of the dwellings in the metropolitan area; 2) investigate which attributes are linked to the residential location choice of the different types of household arrangements and to analyze the influence that accessibility to different opportunities has on their choice of location and; 3) investigate the household's location patterns considering different types of housing settlements (such as favelas and gated communities), and accessibility by public transport. These are important aspects for urban planning investments in transport systems and transport policies especially in relation to their possibilities to counter balance the asymmetric dispute for residential locations by making a more fair distribution of the potential access to the matrix of urban opportunities. 


\section{References}

Albacete, X. 2019. Accessibility at the household level using the structural accessibility layer: A forecast of potential future travel behaviour based on self-selection of residential location. Papers in Regional Science, 98(1):515-538.

Alves, J. E. D. and S. Cavenaghi. 2016. Déficit habitacional, familias conviventes e condiçóes de moradia, volume 3 of Séries Demográficas. Associação Brasileira de Estudos Populacionais.

Arretche, M. 2018. Paths of Inequality in Brazil: A Half-Century of Changes. Springer.

Barros, J. 2012. Exploring urban dynamics in Latin American cities using an agent-based simulation approach. In Agent-based models of geographical systems, pp. 571-589. Springer.

Beckmann, M. J. 1973. Equilibrium models of residential land use. Regional and Urban Economics, 3(4):361-368. ISSN 00343331. doi: 10.1016/0034-3331(73)90029-8. URL http://linkinghub. elsevier.com/retrieve/pii/0034333173900298.

Boisjoly, G., A. I. Moreno-Monroy, and A. El-Geneidy. 2017. Informality and accessibility to jobs by public transit: Evidence from the São Paulo Metropolitan Region. Journal of Transport Geography, 64:89-96.

Brazilian Institute of Geography and Statistics. 2010. Censo Demografico. Visited on July 2015, URL http://www.ibge.gov.br/home/.

Caldeira, T. P. 2000. City of walls: crime, segregation, and citizenship in São Paulo. Univ of California Press.

Castells, M. 1979. The Urban Question: A Marxist Approach. Cambridge: The MIT Press. 502 p.

Cavenaghi, S. and J. E. D. Alves. 2012. Tendências Demográficas, dos Domicílios e das Famílias no Brasil. Aparte Inclusão Social, pp. 1-33. URL http://www.ie.ufrj.br/aparte/.

Center for Metropolitan Studies. 2013. EDUCAÇÃO: Escolas Públicas e Particulares da RMSP. Visited on July 2016, URL http://www.fflch.usp.br/centrodametropole/.

Center for Metropolitan Studies. 2016. Base de Logradouros. Visited on July 2016, URL http:// www.fflch.usp.br/centrodametropole/.

Champion, A. 2001. A changing demographic regime and evolving poly centric urban regions: Consequences for the size, composition and distribution of city populations. Urban Studies, 38(4):657677. ISSN 0042-0980. doi: 10.1080/00420980120035277. URL http://journals.sagepub.com/ doi/10.1080/00420980120035277.

Companhia do Metropolitano de São Paulo. 2007. Pesquisa de Origem e Destino. Visited on July 2016, URL https://transparencia.metrosp.com.br/dataset/pesquisa-origem-e-destino.

Couclelis, H. 2000. From Sustainable Transportation to Sustainable Accessibility: Can We Avoid a New Tragedy of the Commons? In Information, Place, and Cyberspace, pp. 341-356. doi: 10.1007/978-3-662-04027-0_20. URL http://link.springer.com/10.1007/978-3-662-04027-0_ 20.

Duarte, G. and R. Silveira Neto. 2015. Estrutura Familiar e Escolha da Localização de Residência nas Cidades: Uma Análise Empírica para o Caso da Região Metropolitana de São Paulo. Desenvolvimento em Questão, 14(33):41. ISSN 2237-6453. doi: 10.21527/2237-6453.2016.33.41-64. URL https://www.revistas.unijui.edu.br/index.php/desenvolvimentoemquestao/article/view/3167.

Estiri, H., A. Krause, and M. P. Heris. 2015. "Phasic" metropolitan settlers: A phase-based model for the distribution of households in US metropolitan regions. Urban Geography, 36(5):777-794. ISSN 0272-3638. doi: 10.1080/02723638.2015.1005921. URL http://dx.doi.org/10.1080/02723638.2015.1005921 http://www.tandfonline.com/doi/full/10. 1080/02723638.2015.1005921.

Feitosa, F., J. Barros, E. Marques, and M. Giannotti. 2021. Measuring changes in residential segregation in São Paulo in the 2000s. In M. Van Ham, T. Tammaru, R. Ubareviien, and H. Janssen, eds., Urban Socio-Economic Segregation and Income Inequality, pp. 507-523. Springer Press. 
Feitosa, F. d. F., R. V. Maretto, and A. M. V. Monteiro. 2017. Struggle for space in coastal cities: A cellular automata model for simulating urban stratification dynamics. Revista Brasileira de Cartografia, 69(8).

Feitosa, F. F., Q. B. Le, and P. L. Vlek. 2011. Multi-agent simulator for urban segregation (masus): A tool to explore alternatives for promoting inclusive cities. Computers, Environment and Urban Systems, 35(2):104-115.

Ferrari, T., A. M. V. Monteiro, and P. V. M. Amaral. 2019. Estrutura familiar e padrões espaciais da escolha residencial. Revista Brasileira de Estudos Regionais e Urbanos, 13(3):405-421.

Fujita, M. 1989. Urban Economic Theory. Cambridge: Cambridge University Press. ISBN 9780511625862. doi: 10.1017/CBO9780511625862. URL http://ebooks.cambridge.org/ref/ id/CBO9780511625862.

Fundação João Pinheiro. 2018. Deficit Habitacional no Brasil 2015. Visited on November 2020, URL http://www.bibliotecadigital.mg.gov.br/consulta/consultaDetalheDocumento.php? iCodDocumento $=76871$.

Guo, J. Y. and C. R. Bhat. 2007. Operationalizing the concept of neighborhood: Application to residential location choice analysis. Journal of Transport Geography, 15(1):31-45.

Hansen, W. G. 1959. How accessibility shapes land use. Journal of the American Institute of Planners, 25(2):73-76. ISSN 0002-8991. doi: 10.1080/01944365908978307. URL http://www. tandfonline.com/doi/abs/10.1080/01944365908978307.

Ingram, D. 1971. The concept of accessibility: A search for an operational form. Regional Studies, 5(2):101-107. ISSN 0034-3404. doi: 10.1080/09595237100185131. URL http://www. tandfonline.com/doi/abs/10.1080/09595237100185131.

Jung, G. and T.-C. Yang. 2016. Household structure and suburbia residence in U.S. metropolitan areas: Evidence from the American Housing Survey. Social Sciences, 5(4):74. doi: 10.3390/socsci5040074.

Kim, J. H., F. Pagliara, and J. Preston. 2005. The intention to move and residential location choice behaviour. Urban Studies, 42(9):1621-1636.

Leone, E. T., A. G. Maia, and P. E. Baltar. 2010. Mudanças na composição das famílias e impactos sobre a redução da pobreza no Brasil. Economia e Sociedade, 19(1):59-77. ISSN 01040618. doi: 10.1590/S0104-06182010000100003. URL http://www.scielo.br/scielo.php?script= sci_arttext\&pid=S0104-06182010000100003\&lng=pt\&tlng=pt.

Lima Neto, V. C., B. A. Furtado, and C. Krause. 2013. Estimativas do déficit habitacional brasileiro (PNAD 2007-2012). Instituto de Pesquisa Econômica Aplicada (Ipea).

Marques, E. C. and R. M. Bichir. 2003. Public policies, political cleavages and urban space: state infrastructure policies in são paulo, brazil, 1975-2000. International Journal of Urban and Regional Research, 27(4):811-827.

Marques, E. C. L. 2016. São Paulo in the twenty-first century: Spaces, heterogeneities, inequalities. Routledge.

Ministry of Labor and Employment. 2013. Annual Report of Social Information. Technical report, Ministério do Trabalho e Emprego, Brasilia. Visited on June 2016, URL http://trabalho.gov.br/ rais.

Moreno-Monroy, A. I. and F. R. Ramos. 2020. The impact of public transport expansions on informality: the case of the são paulo metropolitan region. Research in Transportation Economics, p. 100928.

Owen, A. and D. M. Levinson. 2015. Modeling the commute mode share of transit using continuous accessibility to jobs. Transportation Research Part A: Policy and Practice, 74:110-122. ISSN 09658564. doi: 10.1016/j.tra.2015.02.002. URL http://dx.doi.org/10.1016/j.tra.2015.02. 002https://linkinghub.elsevier.com/retrieve/pii/S0965856415000191.

Páez, A., S. Farber, R. Mercado, M. Roorda, and C. Morency. 2013. Jobs and the single parent: An analysis of accessibility to employment in toronto. Urban Geography, 34(6):815-842. ISSN 02723638. doi: $10.1080 / 02723638.2013 .778600$. 
Páez, A., R. Gertes Mercado, S. Farber, C. Morency, and M. Roorda. 2010. Relative accessibility deprivation indicators for urban settings: Definitions and application to food deserts in Montreal. Urban Studies, 47(7):1415-1438. ISSN 0042-0980. doi: 10.1177/0042098009353626. URL http://journals.sagepub.com/doi/10.1177/0042098009353626.

Paulista Company of Metropolitan Planning. 2010. Mapeamento do Uso e Ocupação do Solo da RMSP. Visited on February 2017, URL https://www.emplasa.sp.gov.br.

Pitombo, C. S. 2003. Análise do comportamento subjacente ao encadeamento de viagens através do uso minerador de dados. Ph.D. thesis, Universidade de São Paulo.

Reggiani, A., P. Bucci, and G. Russo. 2011. Accessibility and impedance forms: Empirical applications to the German commuting network. International Regional Science Review, 34(2):230-252. ISSN 01600176. doi: 10.1177/0160017610387296.

Rezaei, A. and Z. Patterson. 2018. Preference stability in household location choice: Using crosssectional data from three censuses. Research in Transportation Economics, 67:44-53.

Ribeiro, M. P., R. Luis, C. Curi, and F. Carlos. 2019. Desigualdade E Estrutura Familiar : Uma Análise. Revista de Desenvolvimento Econômico, 1(42):33-60. doi: 10.21452/rde.v1i42.5933.

Santos, M. 2013. A urbanização Brasileira, volume 6. Edusp.

Santos, M. and B. Kayser. 1971. Espaces et villes du tiers monde. Revue Tiers Monde, pp. 7-12.

Schwanen, T., M. J. Dijst, and F. M. Dieleman. 2005. The relationship between land use and travel patterns: Variations by household type. In K. Williams, ed., Spatial Planning, Urban Forms and Sustainable Transport, 1982, chapter 2, pp. 17-41. Routledge; 1 edition. ISBN 9780754642510.

SECOVISP. 2018. Anuário do Mercado Imobiliário | 2018 1. Technical report, Housing Union SECOVI, SP, Sao Paulo. URL https://www.secovi.com.br/downloads/url/2394.

Slovic, A. D., D. B. Tomasiello, M. Giannotti, M. de Fatima Andrade, and A. C. Nardocci. 2019. The long road to achieving equity: Job accessibility restrictions and overlapping inequalities in the city of São Paulo. Journal of Transport Geography, 78:181-193.

Srour, I. M., K. M. Kockelman, and T. P. Dunn. 2002. Accessibility indices: Connection to residential land prices and location choices. Transportation Research Record, 1805(1):25-34.

Vecchio, G., I. Tiznado-Aitken, and R. Hurtubia. 2020. Transport and equity in Latin America: A critical review of socially oriented accessibility assessments. Transport Reviews, 40(3):354-381.

Wajnman, S., C. M. Turra, and C. S. Agostinho. 2006. Estrutura domiciliar e distribuição da renda familiar no Brasil. In R. P. d. BARROS, M. N. FOGUEL, and G. ULYSSEA, eds., Desigualdade de Renda no Brasil: uma análise da queda recente, volume 1, chapter 14, pp. 423-442. Brasília: IPEA.

Weber, J. and M.-P. Kwan. 2008. Evaluating the effects of geographic contexts on individual accessibility: A multilevel approach. Urban Geography, 24(8):647-671. ISSN 0272-3638. doi: 10.2747/0272-3638.24.8.647.

Zondag, B. and M. Pieters. 2005. Influence of accessibility on residential location choice. Transportation Research Record, 1902(1):63-70. 